But those times are past, though not forgotten. And now, on August 8,1873-more than a third of a century afterwardsthe few remaining ones of the actors of those early days, are to meet together in one of the great state of Iowa's beautiful groves, to live those scenes over again; to join hands that have long been parted; to refresh old memories; to laugh at the ludicrous side of the past. and to drop a tear over the graves of departed ones that have fallen by the way.

It will be good to be there.

\title{
FOLKLORE CONCERNING THE MEADOW LARK
}

The meadow lark is a great favorite with the people of the Dakota nation. An old man of that nation was asked if his people ever used the meadow lark for food. He said they did not. When it was said that white men sometimes eat them, he said he knew that. Then, when asked why Dakotas would not eat the meadow lark, he said, "We think too much of them. They are our friends." They call the meadow lark "the bird of promise," and "the bird of many gifts," for they say it promises good things to its friends, the Dakotas. They apply words of the Dakota language to the songs of the bird. They say it calls to the people with promises, words of counsel, advice, encouragement, and good cheer. They say it gives words of advice on all manner of subjects. One of the things which it used to sing out to the people was "Koda, pte kizhozho," i. e., "Friends, I whistle for the buffalo," that is to say, it would whistle to call the buffalo in order that its friends, the Dakotas, might supply their needs of meat and clothing.

The white people speak of the United States government as "Uncle Sam," but the people of the Dakota nation call the government "Tunkashila," which means "Grandfather," a term of highest respect. In the summer of 1918, while the United States was at war with Germany, many of the Dakotas said they heard "the bird of promise" singing "Tunkashila ohiyelo!" "Ohiyelo" means "will be victorious," or "will have victory;" so the meadow lark, "the bird of promise," was singing to them, "The United States will have the victory!" 
Copyright of Annals of Iowa is the property of State of Iowa, by \& through the State Historical Society of Iowa and its content may not be copied or emailed to multiple sites or posted to a listserv without the copyright holder's express written permission. However, users may print, download, or email articles for individual use. 